\title{
Sistem Pendukung Keputusan Penentuan Calon Penerima Beasiswa Prestasi di Universitas Amikom Yogyakarta
}

\author{
Muhammad Mariko, Ainul Yaqin \\ Ilmu Komputer, Informatika, Universitas Amikom Yogyakarta, Yogyakarta, Indonesia \\ Email: ${ }^{1}$ muhammad.mariko@ students.amikom.ac.id, ${ }^{2}$ ainulyaqin@amikom.ac.id
}

\begin{abstract}
Abstrak
Universitas Amikom Yogyakarta menyediakan berbagai jenis beasiswa kepada mahasiswa, salah satunya yaitu beasiswa prestasi. proses penyeleksian membutuhkan kecermatan dan juga cepat, agar hasil yang diperoleh sesuai dengan ketentuan, jika proses penyeleksian dilakukan secara manual maka akan membutuhkan waktu yang cukup lama dan mudah terjadi kesalahan. Sistem pendukung keputusan dengan menggunakan metode fuzzy tsukamoto dapat membantu menyeleksi penerima beasiswa dengan melakukan perhitungan matematis oleh system dan menghasilkan nilai bobot kriteria setiap mahasiswa sebagai acuan dalam pengambil keputusan. Berdasarkan hasil penelitian dari setiap bobot kriteria, yaitu IPK, prestasi dan penghasilan orang tua didapatkan hasil uji dengan akurasi sebesar $80 \%$.
\end{abstract}

Kata kunci: Sistem Pendukung Keputusan, Beasiswa Prestasi, Fuzzy Tsukamoto

\section{Abstract}

Amikom Yogyakarta University provides various types of scholarships to students, one of which is an achievement scholarship. the selection process requires precision and also fast, so that the results obtained are in accordance with the provisions, if the selection process is done manually then it will take a long time and easy errors occur. Decision support systems using the Tsukamoto fuzzy method can help select scholarship recipients by performing mathematical calculations by the system and produce weighting criteria for each student as a reference in decision makers. Based on the results of the research of each criteria weight, namely GPA, achievement and assessment of parents obtained test results with an accuracy of $80 \%$.

Keywords: Decission Support System, Achievement, Fuzzy Tsukamoto

\section{PENDAHULUAN}

Beasiswa adalah bantuan dana yang diberikan kepada pelajar untuk keberlangsungan pendidikan yang sedang ditempuh dan juga sebagai bentuk apresiasi atau penghargaan agar dapat mempertahankan serta meningkatkan prestasi sehingga lembaga pendidikan dapat menghasilkan lulusan yang berkualitas. Universitas Amikom Yogyakarta merupakan salah satu perguruan tinggi berbasis teknologi informasi di Yogyakarta. Universitas ini menyediakan berbagai beasiswa untuk mahasiswanya. Beberapa beasiswa yang disediakan di universitas Amikom adalah beasiswa bidikmisi, muamalat, PPA, BP-PPA, PPE BAZAM dan juga beasiswa prestasi.

Direktorat Kemahasiswaan yang mengelola beasiswa tersebut membutuhkan penyeleksian yang cermat tepat dan cepat dalam menentukan calon mahasiswa yang berhak mendapatkan beasiswa tersebut agar bantuan dana yang diberikan tepat sasaran. Seleksi secara manual akan membutuhkan waktu yang cukup lama dan memungkinkan munculnya penilaian yang subjektif dalam proses penyeleksian sehingga penerima beasiswa tidak terseleksi dengan baik.

Sistem pendukung keputusan dapat digunakan untuk membantu dalam menentukan calon mahasiswa penerima beasiswa prestasi, karna sistem pendukung keputusan memiliki kemampuan dalam proses pengambil keputusan terhadap masalah terstruktur atau semi terstruktur [1]. Sistem akan melalukan perhitungan matematis secara komputasi dengan menghasilkan nilai pada bobot kriteria yang diinginkan, sehingga dalam mengambil keputusan dapat dilakukan dengan mudah dan mahasiswa penerima beasiswa dapat terseleksi dengan baik.

Metode yang digunakan dalam sistem pendukung keputusan ini yaitu fuzzy tsukamoto, metode ini dapat digunakan dalam membantu proses penyeleksian beasiswa [2]. Konsep logika fuzzy memiliki kemampuan dalam menangani data yang eksklusif dalam sekelompok data yang cukup homogeny, logika fuzzy juga dapat mengaplikasikan pengalaman para pakar secara langsung tanpa harus melalui proses pelatihan. Metode ini dapat melakukan perhitungan matematis terhadap kriteria himpunan fuzzy yang didapat dari nilia IPK, prestasi dan penghasilan orang tua, hasil akhir dari perhitungan tersebut berupa nilai rata-rata terbobot [3].

\section{METODE PENELITIAN}

\subsection{Sistem Pedukung Keputusan}

Sistem Pendukung Keputusan (SPK) merupakan sistem yang dirancang untuk membantu penyelesaian masalah struktur, semi terstruktur [1], pada penerapanya sistem pendukung keputusan merupakan bentuk kerjasama antara computer dan individu, komputer akan menyelesaikan masalah terstruktur dan individu akan menyelesaikan masalah yang tidak terstruktur.

Tujuan sistem pendukung keputusan yaitu membantu mengambil keputusan atas masalah semi terstruktur, dapat dijadikan pertimbangan, meningkatkan efektifitas keputusan, kecepatan komputasi, 
meningkatkan produktivitas, menjadi dukungan kualitas, bedaya saing dan dapat mengatasi keterbatasan kognitif dalam proses dan penyimpanan.

Karakteristik dari sistem pendukung keputusan itu sendiri yaitu dapat menjadi dukungan diberbagai tingkat management, dapat digunakan untuk individu atau kelompok, mendukung keputusan yang independent atau berurut, selalu menyesuikan diri,mudah dioperasikan dan meningkatkan efektivitas pengambil keputusan yang akurat dan berkualitas[4].

\subsection{Logika Fuzzy}

Logika fuzzy yaitu generalisasi dari logika klasik yang hanya mepunyai nilai 0 dan 1. Logika fuzzy memiliki nilai keanggotaan dari 0 sampai 1, maksudnya adalah objek dapat menjadi anggota dari banyak himpunan dengan derajat keangootaan yang berbeda dalam masing-masing himpunan[5].

Logika Fuzzy dapat dianggap sebagai kotak hitam yang berhubungan antara ruang input menuju ruang output. Kotak hitam yang dimaksudkan adalah metode yang dapat digunakan untuk mengolah data input menjadi output dalam bentuk informasi yang baik [8], seperti yang telihat pada gambar 1 .

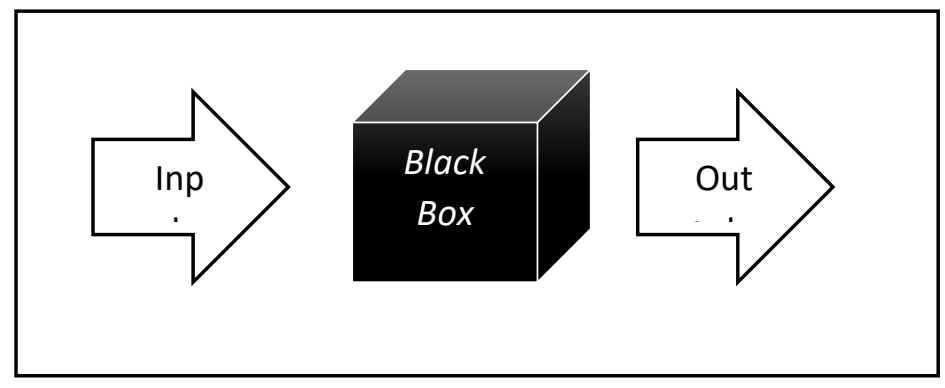

Gambar 1. Diagram Block 'Logika fuzzy Sebagai Black Box'

\subsection{Metode Tsukamoto}

Metode Tsukamoto adalah perluasan dari penalaran monoton, dimana setiap aturan yang berbentuk IF- Then harus direpresentasikan dengan suatu himpunan fuzzy dengan fungsi keanggotaan yang monoton. Sebagai hasilnya, output hasil inferensi dari tiap - tiap aturan diberikan secara tegas (crisp) berdasarkan $\alpha$-predikat (fire strength). Hasil akhirnya diperoleh dengan menggunakan rata - rata terbobot [3].

Kerangka komputasi yang didasarkan pada teori himpunan fuzzy secara garis besar dapat dilihat pada diagram blok proses inferensi fuzzy tsukamoto yang ditunjukan pada gambar 2 .

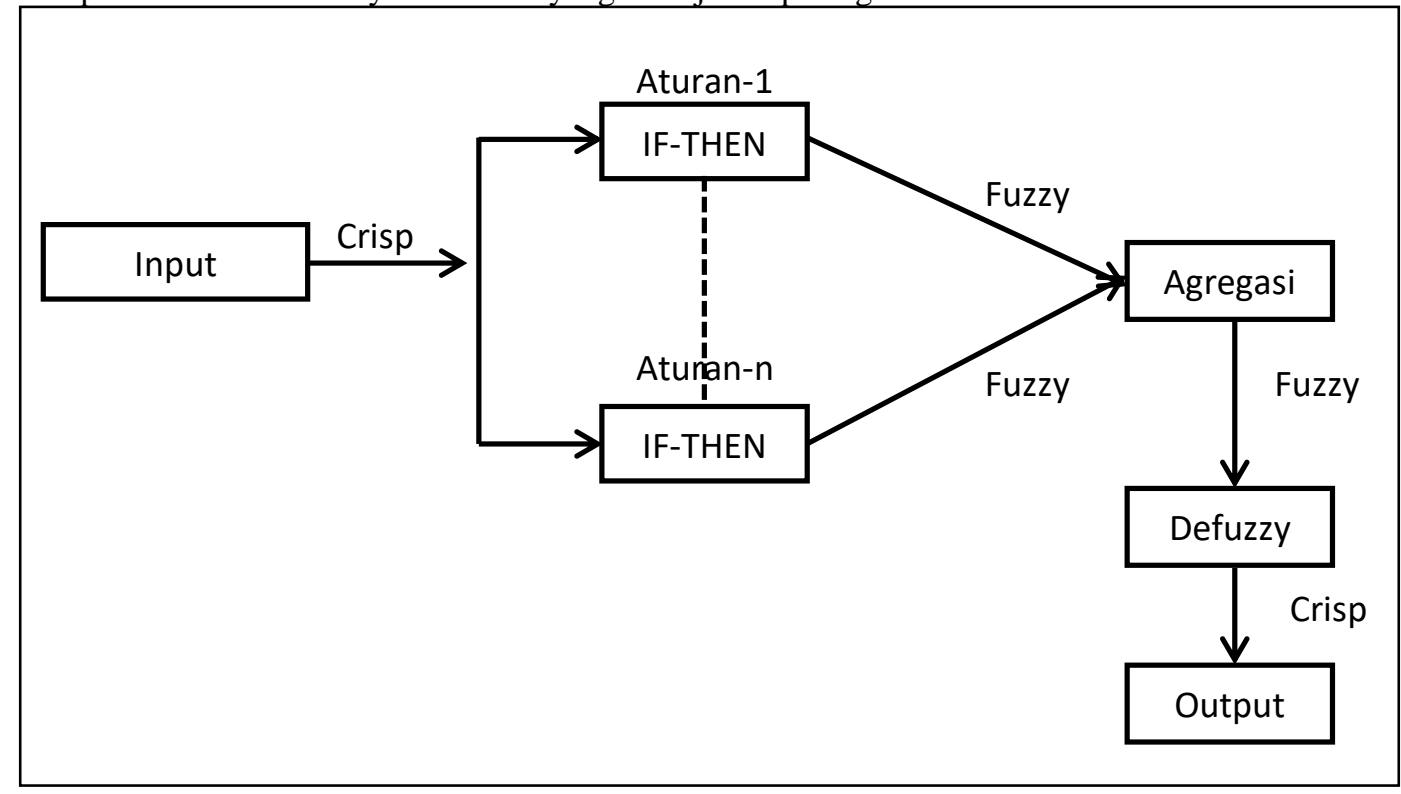

Gambar 2. Diagram Blok Sistem Inferensi Fuzzy Tsukamoto

Sistem Inferensi Fuzzy menerima input crisp. Input ini kemudian dikirim ke basis pengetahuan yang berisi $\mathrm{n}$ aturan fuzzy dalam bentuk IF-THEN. Fire strength dicari pada setiap aturan. Apabila jumlah aturan lebih dari satu, maka dilakukan agregasi dari semua aturan. Selanjutnya, pada hasil agregasi dilakukan defuzzy untuk mendapatkan nilai crisp sebagai output sistem.

Pada dasarnya, metode Tsukamoto mengaplikasikan penalaran monoton pada setiap aturannya. pada metode ini setiap konsekuen pada aturan yang berbentuk IF-THEN harus direpresentasikan dengan suatu 
himpunan fuzzy dengan fungsi keanggotaan yang monoton. Output hasil inferensi dari tiap - tiap aturan diberikan secara tegas (crisp) berdasarkan $\alpha$-predikat (fire strength) dan agregasi antar aturan, kemudian hasil akhir dari algoritma fuzzy diperoleh dengan menggunakan defuzzy [3].

\subsection{Action Research (Penelitian Tindakan)}

Action Research atau Penelitian tindakan adalah suatu kerangka penelitian pemecahan masalah, dimana terjadi kolaborasi antara peneliti dengan client dalam mencapai tujuan [6].Penelitian tindakan bertujuan untuk memperoleh pengetahuan untuk situasi atau sasaran khusus dari pada pengetahuan yang secara ilmiah tergeneralisasi. Pada umumnya penelitian tindakan untuk mencapai beberapa hal yaitu penigkatan praktik, peningkatan (pengembangan profesional) pemahaman praktik dan praktisinya dan peningkatan situasi tempat pelaksanaan praktik [7]. Penelitian tindakan menggabungkan kegiatan penelitian dengan menggunakan hasil penelitian atau pengumpulan data. Kegiatan ini dilakukan secara timbal balik membentuk model proses seperti spiral yang tersusun dari rencana, tindakan, pengamatan dan refleksi [8]. Seperti yang ditunjukan gambar 3.

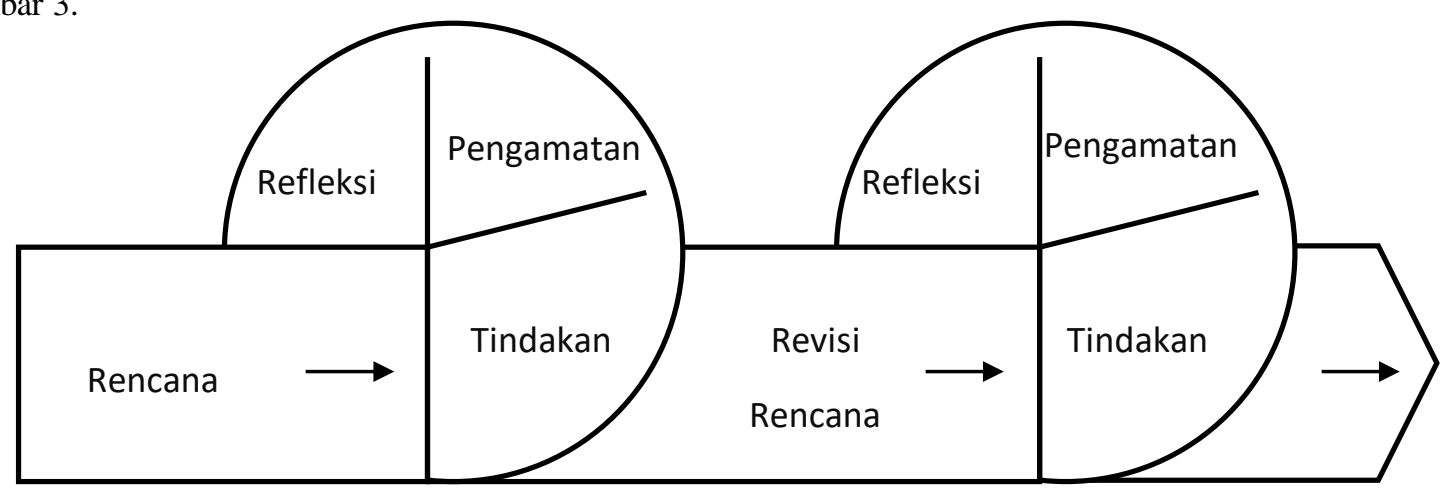

Gambar 3. Diagram siklus action research

\section{ANALISA DAN PEMBAHASAN}

Pada bagian ini berisi analisa, hasil serta pembahasan dari topik penelitian, yang bisa di buat terlebih dahulu metodologi penelitian. Bagian ini juga merepresentasikan penjelasan yang berupa penjelasan, gambar, tabel dan lainnya.

\subsection{Menentukan Variabel Input}

Variabel input yang digunakan dalam penyeleksian beasiswa prestasi ada tiga, yaitu :

a. Indeks Prestasi Kumulatif (IPK).

b. prestasi ko/ekstrakurikuler dan

c. penghasilan orang tua

\subsection{Menentukan Variabel Output}

Variabel output pada penyeleksian beasiswa prestasi mengunakan tingkat kelayakan penerima beasiswa, apakah tingkat kelayakan mahasiswa tersebut rendah atau tinggi. Tingkat kelayakan digunakan sebagai acuan untuk mebantu dalam pengambil keputsan, jika tingkat kelayakan mahasiswa semakin tinggi maka mahasiswa tersebut akan menjadi prioritas utama sebagai calon penerima beasiwa.

\subsection{Menentukan Domain Setiap Variabel}

Selain menentukan variabel input dan output dibutuhkan juga menentukan nilai domain yang akan digunakan oleh sistem sebagai parameter perhitungan, nilai domain yang digunakan yaitu:

a. Indek Prestasi Kumulatif [0, 4]

b. Prestasi $[0,100]$

c. Penghasilan orang tua [0, 3000000]

d. Kelayakan $[0,100]$

\subsection{Menentukan Himpunan dan Nilai Keanggotaan Setiap Variabel}

\subsubsection{Indeks Prestasi Kumulatif (IPK)}

Indeks prestasi kumulatif (IPK) merupakan salah satu syarat yang digunakan untuk menentukan prestasi mahasiswa. Nilai IPK terbagi mejadi empat himpunan yaitu Rendah, Cukup, Sedang dan Tinggi, Setiap himpunan memiliki nilai derajat keanggotaan yang berbeda seperti yang terlihat pada tabel 1 dan gambar 4. 
Tabel 1. Himpunan Fuzzy Variabel IPK

\begin{tabular}{clc}
\hline Variabel & Domain & Himpunan Fuzzy \\
\hline \multirow{4}{*}{ IPK } & $2.5-2.7$ & Rendah \\
& $2.5-3$ & Cukup \\
& $2.7-3.5$ & Sedang \\
& $3.3-4$ & Tinggi \\
\hline
\end{tabular}

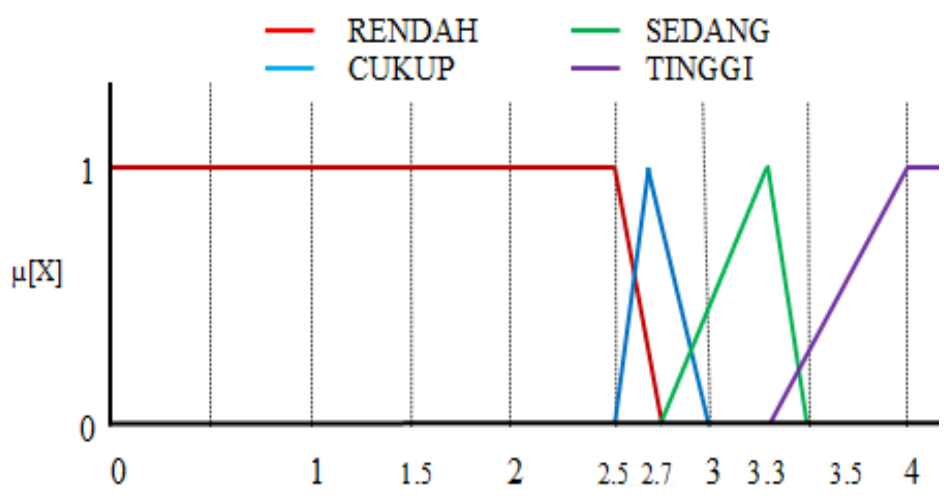

Gambar 4. Kurva indek prestasi kumulatif (IPK)

\subsubsection{Prestasi}

Variabel kedua yang digunakan untuk menentukan bobot nilai pada sistem pendukung keputusan yaitu nilia prestasi. Nilai ini didapatkan dari keaktivan mahasiswa dalam mengikuti berbagai kegiatan dan kompetisi, baik itu sebagai partisipasi, peserta maupun sebagai juara, kemudian nilai tersebut dijumlah mejadi nilai total prestasi. Nilai prestasi memiliki tiga himpunan yaitu rendah, Sedang dan tinggi seperti yang terlihat pada tabel 2 dan gambar 5.

Tabel 2. Himpunan Fuzzy Variabel Prestasi

\begin{tabular}{clc}
\hline Variabel & Domain & Himpunan Fuzzy \\
\hline \multirow{3}{*}{ Prestasi } & $10-50$ & Rendah \\
& $30-70$ & Sedang \\
& $60-100$ & Tinggi \\
\hline
\end{tabular}

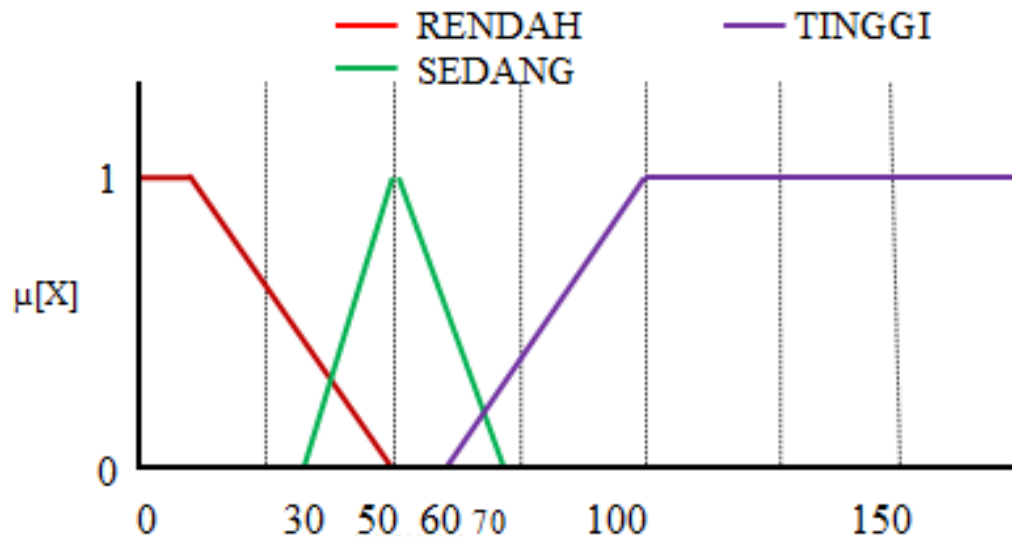

Gambar 5. Kurva Prestasi

\subsubsection{Penghasilan Orang Tua}

Penghasilan orang tua adalah variabel terakhir yang digunakan untuk menentukan bobot nilai mahasiswa di sistem, himpunan fuzzy untuk penghasilan orang tua ata tiga yaitu rendah, sedang dan tinggi seperti yang terlihat pada tabel 3 dan gambar 6 .

Tabel 3. Himpunan Fuzzy Penghasilan Orang Tua 


\begin{tabular}{clc}
\hline Variabel & Domain & Himpunan Fuzzy \\
\hline \multirow{2}{*}{ Penghasilan } & $500000-1000000$ & Rendah \\
orang tua & $800000-1500000$ & Sedang \\
& $1400000-2500000$ & Tinggi \\
\hline
\end{tabular}

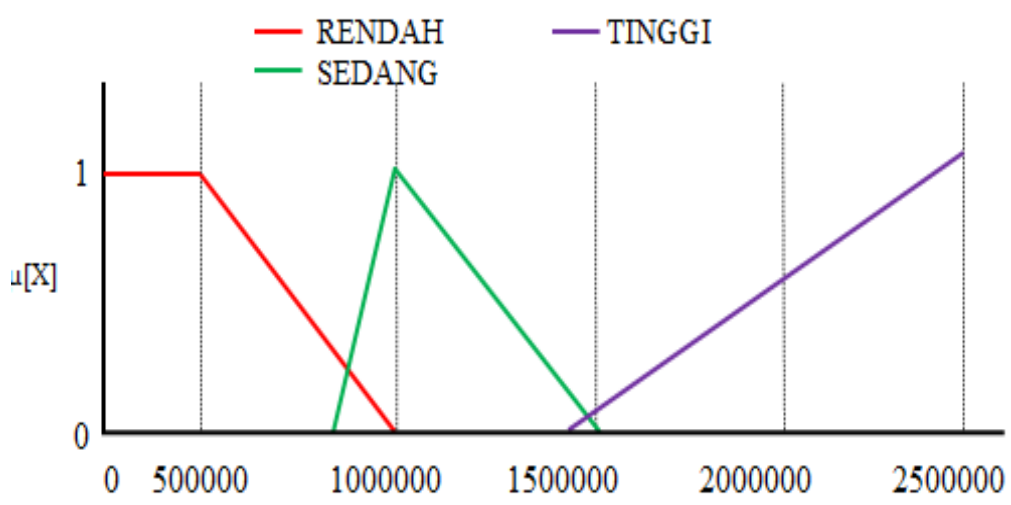

Gambar 6. Kurva Penghasilan Orang Tua

\subsubsection{Kelayakan}

Variabel kelayakan digunakan untuk menentukan keputusan yang akan dibuat oleh sistem. Dari bobot nilai dapat diketahui kelayakan dari setiap mahasiswa untuk dijadikan calon penerima beasiswa. Variabell kelayakan memiki dua himpunan yaitu rendah dan tinggi seperti yang terlihat pada tabel 4 dan gambar 7

Tabel 4. Himpunan Fuzzy Variabel Kelayakan

\begin{tabular}{clc}
\hline Variabel & Domain & Himpunan Fuzzy \\
\hline \multirow{2}{*}{ Kelayakan } & $10-50$ & Rendah \\
& $60-100$ & Tinggi \\
\hline
\end{tabular}

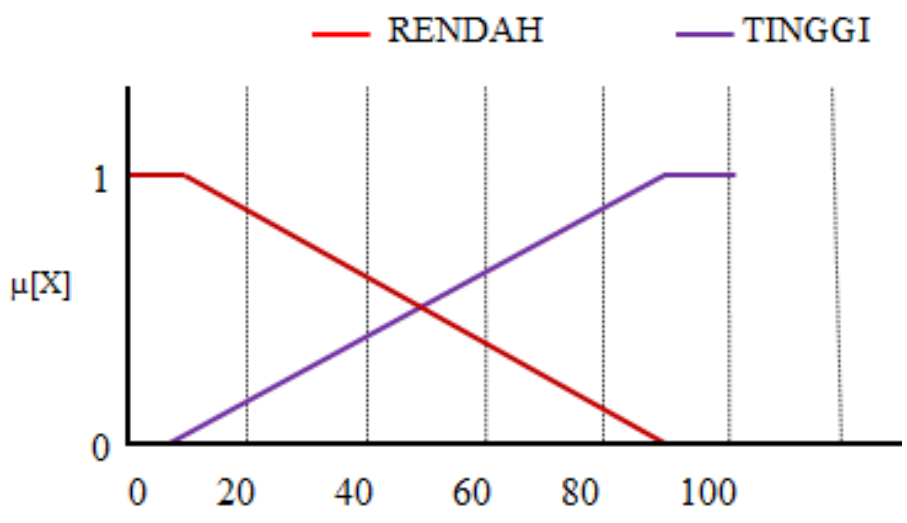

Gambar 7. Kurva Kelayakan

Fungsi keanggotaan pada variabel IPK dapat dirumuskan pada persamaan berikut:

$$
\begin{aligned}
& \text { kelayakan Rendah }[x]=\left\{\begin{array}{cl}
1 ; x \leq 20 \\
\frac{(20-x)}{(90-20)} ; 20 \leq x \leq 90
\end{array}\right. \\
& \text { Kelayakan Tinggi }[x]=\left\{\begin{array}{cl}
\frac{(x-20)}{(90-20)} ; & 20 \leq x \leq 90 \\
1 ; & 90 \leq x
\end{array}\right.
\end{aligned}
$$

\subsection{Membuat Rulebase}

Rulebase digunakan sebagai aturan dasar penentuan keputusan pada alrgoritma fuzzy tsukamoto yang merepresentasikan pengelaman dan pengetahuan expert knowledge kedalam sistem. Contoh aturan kaidah rule base reasoning dalam sistem pendukung keputusan adalah : 
IF (ipk tinggi) AND (prestasi tinggi) AND( penghasilan orang tua rendah) THEN (kelayakan tinggi).

IF (ipk rendah AND ( prestasi rendah AND (penghasilan orang tua tinggi) THEN (kelayakanan rendah), dll

Pada penelitian ini rulebase yang digunakan ada 36 aturan yang didapat dari banyaknya jumlah himpunan dari semua variabel. Adapun rulebase dari sistem pendukung keputusan ini dapat dilihat pada tabel 5.

Tabel 5. Rulebase

\begin{tabular}{|c|c|c|c|c|c|c|c|c|}
\hline NO & & IPK & & PRESTASI & & POT & & KELAYAKAN \\
\hline 1 & IF & RENDAH & AND & RENDAH & AND & RENDAH & THEN & RENDAH \\
\hline 2 & IF & RENDAH & AND & RENDAH & AND & SEDANG & THEN & RENDAH \\
\hline 3 & IF & RENDAH & AND & RENDAH & AND & TINGGI & THEN & RENDAH \\
\hline 4 & IF & RENDAH & AND & SEDANG & AND & RENDAH & THEN & RENDAH \\
\hline 5 & IF & RENDAH & AND & SEDANG & AND & SEDANG & THEN & RENDAH \\
\hline 6 & IF & RENDAH & AND & SEDANG & AND & TINGGI & THEN & RENDAH \\
\hline 7 & IF & RENDAH & AND & TINGGI & AND & RENDAH & THEN & TINGGI \\
\hline 8 & IF & RENDAH & AND & TINGGI & AND & SEDANG & THEN & RENDAH \\
\hline 9 & IF & RENDAH & AND & TINGGI & AND & TINGGI & THEN & RENDAH \\
\hline 10 & IF & CUKUP & AND & RENDAH & AND & RENDAH & THEN & RENDAH \\
\hline 11 & IF & CUKUP & AND & RENDAH & AND & SEDANG & THEN & RENDAH \\
\hline 12 & IF & CUKUP & AND & RENDAH & AND & TINGGI & THEN & RENDAH \\
\hline 13 & IF & CUKUP & AND & SEDANG & AND & RENDAH & THEN & TINGGI \\
\hline 14 & IF & CUKUP & AND & SEDANG & AND & SEDANG & THEN & RENDAH \\
\hline 15 & IF & CUKUP & AND & SEDANG & AND & TINGGI & THEN & RENDAH \\
\hline 16 & IF & CUKUP & AND & TINGGI & AND & RENDAH & THEN & TINGGI \\
\hline 17 & IF & CUKUP & AND & TINGGI & AND & SEDANG & THEN & TINGGI \\
\hline 18 & IF & CUKUP & AND & TINGGI & AND & TINGGI & THEN & RENDAH \\
\hline 19 & IF & SEDANG & AND & RENDAH & AND & RENDAH & THEN & RENDAH \\
\hline 20 & IF & SEDANG & AND & RENDAH & AND & SEDANG & THEN & RENDAH \\
\hline 21 & IF & SEDANG & AND & RENDAH & AND & TINGGI & THEN & RENDAH \\
\hline 22 & IF & SEDANG & AND & SEDANG & AND & RENDAH & THEN & TINGGI \\
\hline 23 & IF & SEDANG & AND & SEDANG & AND & SEDANG & THEN & TINGGI \\
\hline 24 & IF & SEDANG & AND & SEDANG & AND & TINGGI & THEN & RENDAH \\
\hline 25 & IF & SEDANG & AND & TINGGI & AND & RENDAH & THEN & TINGGI \\
\hline 26 & IF & SEDANG & AND & TINGGI & AND & SEDANG & THEN & TINGGI \\
\hline 27 & IF & SEDANG & AND & TINGGI & AND & TINGGI & THEN & RENDAH \\
\hline 28 & IF & TINGGGI & AND & RENDAH & AND & RENDAH & THEN & TINGGI \\
\hline 29 & IF & TINGGGI & AND & RENDAH & AND & SEDANG & THEN & TINGGI \\
\hline 30 & IF & TINGGGI & AND & RENDAH & AND & TINGGI & THEN & RENDAH \\
\hline 31 & IF & TINGGGI & AND & SEDANG & AND & RENDAH & THEN & TINGGI \\
\hline 32 & IF & TINGGGI & AND & SEDANG & AND & SEDANG & THEN & TINGGI \\
\hline 33 & IF & TINGGGI & AND & SEDANG & AND & TINGGI & THEN & TINGGI \\
\hline 34 & IF & TINGGGI & AND & TINGGI & AND & RENDAH & THEN & TINGGI \\
\hline 35 & IF & TINGGGI & AND & TINGGI & AND & SEDANG & THEN & TINGGI \\
\hline 36 & IF & TINGGGI & AND & TINGGI & AND & TINGGI & THEN & TINGGI \\
\hline
\end{tabular}

\subsection{Melakukan Defuzzyfikasi}

Defuzzyfikasi digunakan untuk mendapatkan hasil akhir dari proses perhitungan fuzzy tsukamoto, nilai tersebut didapat menggunakan metode weighted average (rata - rata terbobot). Metode ini mengambil nilai rata-rata dengan menggunakan pembobotan berupa derajat keanggotaan. Persamaan yang digunakan pada proses dfuzzyfikasi dengan metode weighted average yiatu :

$$
z=\frac{a_{1} * z_{1}+a_{2} * z_{2}}{a_{1}+a_{2}}
$$

Keterangan:

$$
\begin{array}{ll}
\mathrm{z} & =\text { hasil akhir output } \\
\mathrm{a} 1 & =\text { Nilai Keanggotaan min dari aturan ke-1 } \\
\mathrm{z} 1 & =\text { Nilai maximum himpunan dari fungsi impilkasi aturan ke-1 } \\
\mathrm{a} 2 & =\text { Nilai keanggotaan min dari aturan ke-2 } \\
\mathrm{z} 2 & =\text { Nilai maximum himpunan dari fungsi impilkasi aturan ke-2 }
\end{array}
$$




\section{IMPLEMENTASI}

Data yang digunakan pada penelitian ini yaitu data mahasiswa Universitas Amikom Yogyakarta angkatan 2018 dengan jumlah 40 mahasiswa yang memiliki nilai yang berbeda setiap variable inputnya. Seperti yang terlihat pada tabel 5 .

Tabel 6. Data Uji

\begin{tabular}{|c|c|c|c|c|c|}
\hline No & Nim & Nama & IPK & Prestasi & POT \\
\hline 1 & 15.11 .9051 & Aan Nujumul Maruf & 3.8 & 6 & 10000000 \\
\hline 2 & 15.11 .9185 & Abinda Dwi Nur Ahmad & 3.9 & 120 & 4000000 \\
\hline 3 & 16.11 .0161 & Andia Enggar Mayasari & 3.5 & 45 & 6096000 \\
\hline 4 & 15.11 .8671 & Arifa Satria Dwi Cahya & 3.9 & 13 & 18000000 \\
\hline 5 & 15.11 .8912 & Beta Priyoko & 3.7 & 81 & 16686600 \\
\hline 6 & 16.02 .9285 & Chalindra anwar & 3.4 & 36 & 11846700 \\
\hline 7 & 16.11 .0287 & CHARNANTYA SIDIQ & 3.5 & 22 & 7926799 \\
\hline 8 & 15.11 .8837 & David Putra Prasetiya & 3.6 & 25 & 35636400 \\
\hline 9 & 16.11 .0644 & Desi Mariana Manik & 3.4 & 42 & 3428571 \\
\hline 10 & 15.11.9092 & Dhian Prianto & 3.6 & 74 & 9000000 \\
\hline 11 & 16.11 .0610 & Dyno Nurbagyo & 3.6 & 89 & 62997600 \\
\hline 12 & 16.11 .0566 & Edy Samudra & 3.6 & 63 & 14558433 \\
\hline 13 & 16.11 .0548 & Fajar Dwi Insani & 3.6 & 74 & 7500000 \\
\hline 14 & 15.11 .9332 & FAKHRUL ZAEIN & 3.9 & 48 & 7500000 \\
\hline 15 & 17.22 .1960 & IGA MAWARNI & 3.8 & 18 & 1800000 \\
\hline 16 & 16.11.0697 & Intan Aprilia & 3.7 & 79 & 17176500 \\
\hline 17 & 16.02 .9408 & Ismi Nurul Habibah & 3.5 & 20 & 20996000 \\
\hline 18 & 16.11 .0592 & IWAN DWI PRASETYO & 3.7 & 136 & 3000000 \\
\hline 19 & 16.11 .0682 & Kukuh Syaifudin & 3.8 & 85 & 12000000 \\
\hline 20 & 15.11 .9122 & LM ANANG BRILYANSYAH & 3.7 & 66 & 10059600 \\
\hline 21 & 15.12 .8778 & Mohammad Abdul wachid & 3.7 & 31 & 6000000 \\
\hline 22 & 15.11 .8937 & Muhammad Mariko & 3.9 & 129 & 6000000 \\
\hline 23 & 15.12 .8892 & Muhammad Resa Arif Yudianto & 4 & 49 & 8999994 \\
\hline 24 & 16.12 .9155 & Nur Aziz Nugroho & 4 & 12 & 192000000 \\
\hline 25 & 16.02 .9400 & Nurul Fatmawati & 3.9 & 38 & 9000000 \\
\hline 26 & 16.02 .9461 & Nurul Latifah & 3.9 & 19 & 9000000 \\
\hline 27 & 15.11 .8696 & Oktavia & 3.8 & 86 & 24000000 \\
\hline 28 & 15.12 .8789 & Ramadhan Fajariyanto & 3.9 & 57 & 8758110 \\
\hline 29 & 15.11 .8685 & RICHO DEA PRATAMA & 3.6 & 15 & 9000000 \\
\hline 30 & 17.02 .0064 & Setia Tri Yuliani & 3.3 & 17 & 10000000 \\
\hline 31 & 16.01 .3837 & Siti Fatonah & 3.8 & 91 & 10800000 \\
\hline 32 & 17.22 .1958 & Tiara Anggun Rakhmawati & 3.8 & 50 & 2880000 \\
\hline 33 & 16.11 .0491 & Timur Dian Radha Sejati & 3.8 & 77 & 8956080 \\
\hline 34 & 17.12 .0448 & Umi Nur Lisa & 3.8 & 5 & 14014800 \\
\hline 35 & 15.12 .8490 & Wahyu Kuncoro & 3.9 & 21 & 2000000 \\
\hline 36 & 16.11 .0538 & Wahyu Puji Lestari & 3.9 & 107 & 12405600 \\
\hline 37 & 15.11 .8821 & Yogi Saputra & 3.8 & 54 & 20000000 \\
\hline 38 & 16.02 .9251 & Yordan erlangga & 3.4 & 13 & 3000000 \\
\hline 39 & 15.11 .9359 & Yugana Firda Syuari & 3.4 & 183 & 10830000 \\
\hline 40 & 15.11 .9173 & Yuliana astute & 3.5 & 93 & 12000000 \\
\hline
\end{tabular}

Semua data uji tersebut akan diinputkan kedalam sistem, kemudian sistem akan melakukan perhitungan sesuai dengan persamaan yang telah diterapkan kedalam sistem.Data yang diinputkan akan dihitung oleh sistem untuk mencari bobot nilai setiap mahasiswa yang kemudian akan diurutkan berdasarkan bobot nilai tertinggi sehingga memudahkan petugas penyeleksi dalam memilih calon penerima beasiswa yang telah direkomendasikan sistem berdasarkan nilai bobot mahasiswa. Tampilan sistem hasil perhitungan dapat dilihat pada gambar 8 

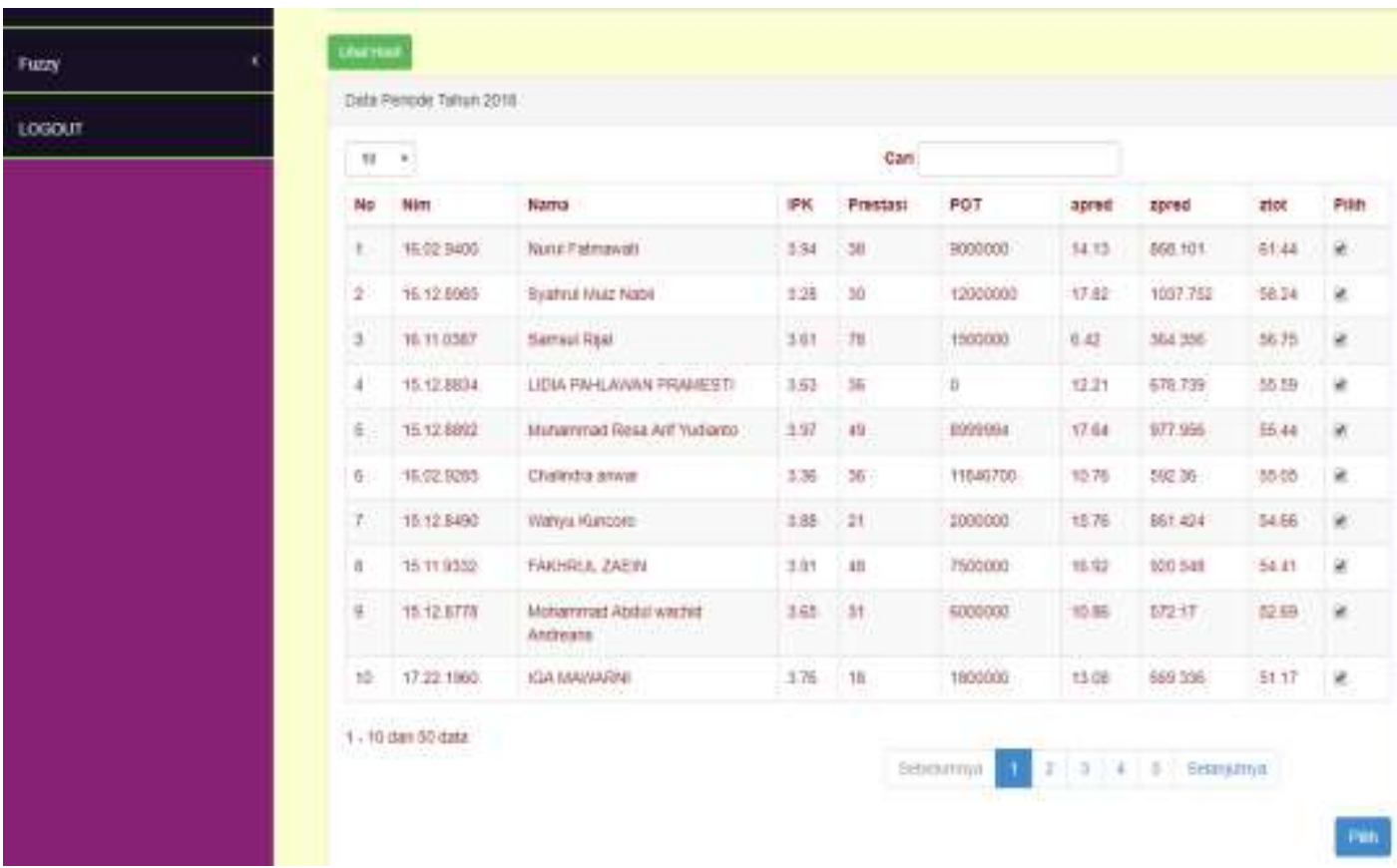

Gambar 8. Tampilan Sistem Hasil Perhitungan

Setelah mendapatkan nilai bobot dari setiap mahasiswa, sistem akan menampilkan kepada user untuk melakukan tahap seleksi. User atau petugas penyeleksi calon penerima beasiswa prestasi cukup menekan button pilih apabila mahasiwa tersebut layak mendapatkan beasiwa kemudian data mahasiwa yang terpilih akan disimpan kedalam database atau dicetak. Tampilan sistem hasil seleksi dapat dilihat pada gambar 9.

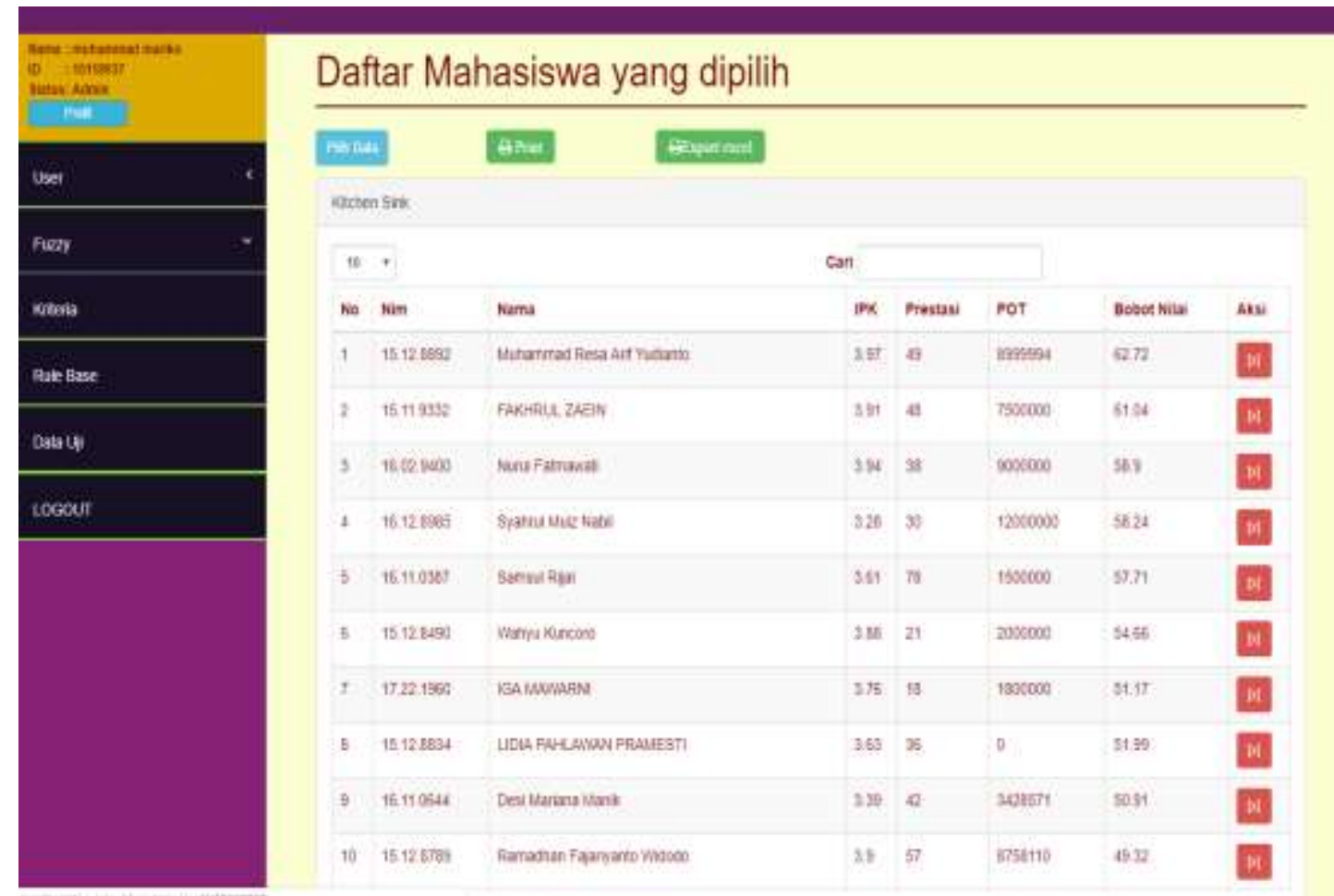

Gambar 9. Tampilan Sistem Hasil Seleksi

Setelah mendapatkan calon mahasiswa yang mendapat beasiwa, sistem juga dapat menghasilkan output berupa laporan. Membuat laporan merupakan proses terakhir dari perhitungan sistem, laporan merupakan hasil rekapitulasi dari data mahasiswa dan bobot nilai dari sistem. laporan dapat dibuat dalam bentuk file pdf, seperti yang terlihat pada gambar 10 . 


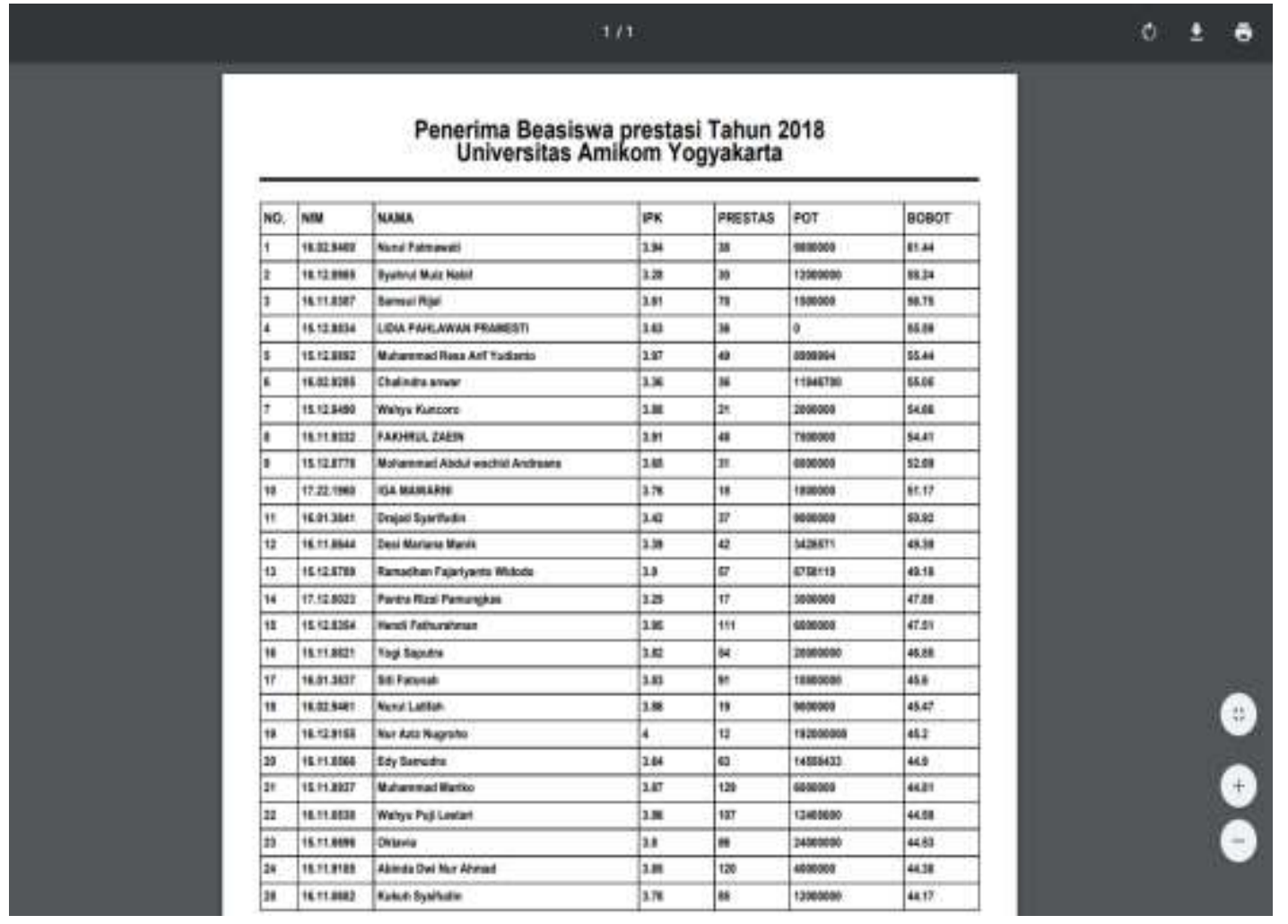

Gambar 10. Laporan

Nilai bobot setiap mahasiswa yang dihitung oleh sistem akan dibandingkan dengan perhitungan yang dilakukan oleh expert knowladge. Pengujian ini dilakukan mencari tingkat dan kelayakan sistem apakah sistem pendukung keputusan tersebut dapat dijadikan pedoman untuk membantu penyeleksian penerima beasiswa atau tidak. Untuk melakukan pengujian diperlukan validasi terlebih dulu untuk mengetahui kesesuain keputusan antara expert knowladge dan sistem, hasil validasi dapat dilihat pada tabel 7.

Tabel 7. Validasi kesesuaian hasil sistem dan manual

\begin{tabular}{|c|c|c|c|c|c|c|c|c|c|}
\hline \multirow{2}{*}{ No } & \multirow{2}{*}{$\mathrm{Nim}$} & \multirow{2}{*}{ Nama } & \multicolumn{3}{|c|}{ Kriteria } & \multirow{2}{*}{$\begin{array}{c}\text { Hasil } \\
\text { Uji }\end{array}$} & \multicolumn{2}{|c|}{ Kelayakan } & \multirow[t]{2}{*}{ Kesesuaian } \\
\hline & & & IPK & Prestasi & POT & & Manual & Sistem & \\
\hline 1 & 15.11 .9051 & $\begin{array}{l}\text { Aan Nujumul } \\
\text { Maruf }\end{array}$ & 3.8 & 6 & 10000000 & 35.26 & Rendah & Rendah & Sesuai \\
\hline 2 & 15.11 .9185 & $\begin{array}{l}\text { Abinda Dwi } \\
\text { Nur Ahmad }\end{array}$ & 3.9 & 120 & 4000000 & 44.38 & Tinggi & Tinggi & Sesuai \\
\hline 3 & 16.11 .0161 & $\begin{array}{l}\text { Andia Enggar } \\
\text { Mayasari }\end{array}$ & 3.5 & 45 & 6096000 & 40 & Rendah & Rendah & Sesuai \\
\hline 4 & 15.11 .8671 & $\begin{array}{l}\text { Arifa Satria } \\
\text { Dwi Cahya }\end{array}$ & 3.9 & 13 & 18000000 & 43.16 & Tinggi & Rendah & $\begin{array}{l}\text { Tidak } \\
\text { Sesuai }\end{array}$ \\
\hline 5 & 15.11 .8912 & Beta Priyoko & 3.7 & 81 & 16686600 & 42.48 & Tinggi & Rendah & $\begin{array}{l}\text { Tidak } \\
\text { Sesuai }\end{array}$ \\
\hline 6 & 16.02 .9285 & $\begin{array}{l}\text { Chalindra } \\
\text { anwar }\end{array}$ & 3.4 & 36 & 11846700 & 55.05 & Rendah & Tinggi & $\begin{array}{l}\text { Tidak } \\
\text { Sesuai }\end{array}$ \\
\hline 7 & 16.11 .028 & $\begin{array}{l}\text { CHARNANTY } \\
\text { A SIDIQ }\end{array}$ & 3.5 & 22 & 7926799 & 38.77 & Rendah & Rendah & Sesuai \\
\hline 8 & 15.11 .8837 & $\begin{array}{l}\text { David Putra } \\
\text { Prasetiya }\end{array}$ & 3.6 & 25 & 35636400 & 41.99 & Rendah & Rendah & Sesuai \\
\hline 9 & 16.11 .0644 & $\begin{array}{l}\text { Desi Mariana } \\
\text { Manik }\end{array}$ & 3.4 & 42 & 3428571 & 49.39 & Rendah & Tinggi & $\begin{array}{l}\text { Tidak } \\
\text { Sesuai }\end{array}$ \\
\hline 10 & 15.11 .9092 & Dhian Prianto & 3.6 & 74 & 9000000 & 37.44 & Rendah & Rendah & Sesuai \\
\hline 11 & 16.11 .0610 & Dyno Nurbagyo & 3.6 & 89 & 62997600 & 38.97 & Rendah & Rendah & Sesuai \\
\hline 12 & 16.11 .0566 & Edy Samudra & 3.6 & 63 & 14558433 & 44.9 & Rendah & Tinggi & $\begin{array}{l}\text { Tidak } \\
\text { Sesuai }\end{array}$ \\
\hline
\end{tabular}




\begin{tabular}{|c|c|c|c|c|c|c|c|c|c|}
\hline \multirow{2}{*}{ No } & \multirow{2}{*}{ Nim } & \multirow{2}{*}{ Nama } & \multicolumn{3}{|c|}{ Kriteria } & \multirow{2}{*}{$\begin{array}{l}\text { Hasil } \\
\text { Uji }\end{array}$} & \multicolumn{2}{|c|}{ Kelayakan } & \multirow[t]{2}{*}{ Kesesuaian } \\
\hline & & & IPK & Prestasi & POT & & Manual & Sistem & \\
\hline 13 & 16.11 .0548 & $\begin{array}{l}\text { Fajar Dwi } \\
\text { Insani }\end{array}$ & 3.6 & 74 & 7500000 & 37.55 & Rendah & Rendah & Sesuai \\
\hline 14 & 15.11 .9332 & $\begin{array}{l}\text { FAKHRUL } \\
\text { ZAEIN }\end{array}$ & 3.9 & 48 & 7500000 & 54.41 & Tinggi & Tinggi & Sesuai \\
\hline 15 & 17.22 .1960 & $\begin{array}{l}\text { IGA } \\
\text { MAWARNI }\end{array}$ & 3.8 & 18 & 1800000 & 51.17 & Tinggi & Tinggi & Sesuai \\
\hline 16 & 16.11 .0697 & Intan Aprilia & 3.7 & 79 & 17176500 & 41.09 & Rendah & Rendah & Sesuai \\
\hline 17 & 16.02 .9408 & $\begin{array}{l}\text { Ismi Nurul } \\
\text { Habibah }\end{array}$ & 3.5 & 20 & 20996000 & 35.22 & Rendah & Rendah & Sesuai \\
\hline 18 & 16.11 .0592 & $\begin{array}{l}\text { IWAN DWI } \\
\text { PRASETYO }\end{array}$ & 3.7 & 136 & 3000000 & 39.87 & Tinggi & Rendah & $\begin{array}{l}\text { Tidak } \\
\text { Sesuai }\end{array}$ \\
\hline 19 & 16.11 .0682 & $\begin{array}{l}\text { Kukuh } \\
\text { Syaifudin } \\
\text { LM ANANG }\end{array}$ & 3.8 & 85 & 12000000 & 44.17 & Tinggi & Tinggi & Sesuai \\
\hline 20 & 15.11 .9122 & $\begin{array}{l}\text { BRILYANSYA } \\
\mathrm{H}\end{array}$ & 3.7 & 66 & 10059600 & 43.88 & Rendah & Rendah & Sesuai \\
\hline 21 & 15.12 .8778 & $\begin{array}{l}\text { Mohammad } \\
\text { Abdul wachid }\end{array}$ & 3.7 & 31 & 6000000 & 52.69 & Rendah & Tinggi & $\begin{array}{l}\text { Tidak } \\
\text { Sesuai }\end{array}$ \\
\hline 22 & 15.11 .8937 & $\begin{array}{l}\text { Muhammad } \\
\text { Mariko }\end{array}$ & 3.9 & 129 & 6000000 & 44.81 & Tinggi & Tinggi & Sesuai \\
\hline 23 & 15.12 .8892 & $\begin{array}{l}\text { Muhammad } \\
\text { Resa Arif } \\
\text { Yudianto }\end{array}$ & 4 & 49 & 8999994 & 55.44 & Tinggi & Tinggi & Sesuai \\
\hline 24 & 16.12 .9155 & $\begin{array}{l}\text { Nur Aziz } \\
\text { Nugroho }\end{array}$ & 4 & 12 & 192000000 & 45.2 & Tinggi & Tinggi & Sesuai \\
\hline 25 & 16.02 .9400 & $\begin{array}{l}\text { Nurul } \\
\text { Fatmawati }\end{array}$ & 3.9 & 38 & 9000000 & 61.44 & Tinggi & Tinggi & Sesuai \\
\hline 26 & 16.02 .9461 & Nurul Latifah & 3.9 & 19 & 9000000 & 45.47 & Tinggi & Tinggi & Sesuai \\
\hline 27 & 15.11 .8696 & Oktavia & 3.8 & 86 & 24000000 & 44.53 & Tinggi & Tinggi & Sesuai \\
\hline 28 & 15.12 .8789 & $\begin{array}{l}\text { Ramadhan } \\
\text { Fajariyanto }\end{array}$ & 3.9 & 57 & 8758110 & 49.18 & Tinggi & Tinggi & Sesuai \\
\hline 29 & 15.11 .8685 & $\begin{array}{l}\text { RICHO DEA } \\
\text { PRATAMA }\end{array}$ & 3.6 & 15 & 9000000 & 34.02 & Rendah & Rendah & Sesuai \\
\hline 30 & 17.02 .0064 & $\begin{array}{l}\text { Setia Tri } \\
\text { Yuliani }\end{array}$ & 3.3 & 17 & 10000000 & 41.08 & Rendah & Rendah & Sesuai \\
\hline 31 & 16.01 .3837 & Siti Fatonah & 3.8 & 91 & 10800000 & 45.6 & Tinggi & Tinggi & Sesuai \\
\hline 32 & 17.22 .1958 & $\begin{array}{l}\text { Tiara Anggun } \\
\text { Rakhmawati }\end{array}$ & 3.8 & 50 & 2880000 & 43.95 & Tinggi & Tinggi & Sesuai \\
\hline 33 & 16.11 .0491 & $\begin{array}{l}\text { Timur Dian } \\
\text { Radha Sejati }\end{array}$ & 3.8 & 77 & 8956080 & 43 & Tinggi & Rendah & $\begin{array}{l}\text { Tidak } \\
\text { Sesuai }\end{array}$ \\
\hline 34 & 17.12 .0448 & Umi Nur Lisa & 3.8 & 5 & 14014800 & 34.59 & Rendah & Rendah & Sesuai \\
\hline 35 & 15.12 .8490 & $\begin{array}{l}\text { Wahyu } \\
\text { Kuncoro }\end{array}$ & 3.9 & 21 & 2000000 & 54.66 & Tinggi & Tinggi & Sesuai \\
\hline 36 & 16.11 .0538 & $\begin{array}{l}\text { Wahyu Puji } \\
\text { Lestari }\end{array}$ & 3.9 & 107 & 12405600 & 44.59 & Tinggi & Tinggi & Sesuai \\
\hline 37 & 15.11 .8821 & Yogi Saputra & 3.8 & 54 & 20000000 & 46.85 & Tinggi & Tinggi & Sesuai \\
\hline 38 & 16.02 .9251 & $\begin{array}{l}\text { Yordan } \\
\text { erlangga }\end{array}$ & 3.4 & 13 & 3000000 & 31.34 & Rendah & Rendah & Sesuai \\
\hline 39 & 15.11 .9359 & $\begin{array}{l}\text { Yugana Firda } \\
\text { Syuari }\end{array}$ & 3.4 & 183 & 10830000 & 35.01 & Rendah & Rendah & Sesuai \\
\hline 40 & 15.11 .9173 & Yuliana astute & 3.5 & 93 & 12000000 & 37.04 & Rendah & Rendah & Sesuai \\
\hline
\end{tabular}

Pengujian untuk mengetahui akurasi sistem pada penelitian ini menggunakan metode confusion matrix. pengujian ini dilakukan dengan membandingan hasil dari perhitungan manual dan perhitungan sistem untuk mencari kesesuaian. Data tersebut dikatakan sesuai apabila hasil rekomendasi dari sistem maupun manual sama. setiap proses perhitunganya akan dihitung berdasarkan jumlah True Positive (TP), True Negative(TN), false Positive(FP) dan false Negative(FN). Adapun hasil pengujian dari data tersebut dapat dilihat pada tabel 8. 
Tabel 8. Pengujian Cofusion matrix

\begin{tabular}{lc}
\hline Kriteria Pengujian & Jumlah \\
\hline True Positive (TP) & 16 \\
True Negative (TN) & 16 \\
False Positive (FP) & 4 \\
False Negative (FN) & 4 \\
TOTAL & 40 \\
\hline
\end{tabular}

Penyelesaian :

$$
\begin{aligned}
\text { Accuracy } & =(\mathrm{TP}+\mathrm{TN}) /(\mathrm{TP}+\mathrm{TN}+\mathrm{FP}+\mathrm{FN}) \\
& =(16+16) /(16+16+4+4) \\
& =32 / 40 \\
& =0.8 \\
& =80 \%
\end{aligned}
$$

Dari hasil pernyelesaian tersebut dipereloeh nilai akurasi sistem pendukung keputusan penerima beasiswa prestasi sebesar $80 \%$. persentase hasil pengujian juga diatas dapat dilihat seperti yang tersaji pada diagram pie yang terdapat pada gambar 11

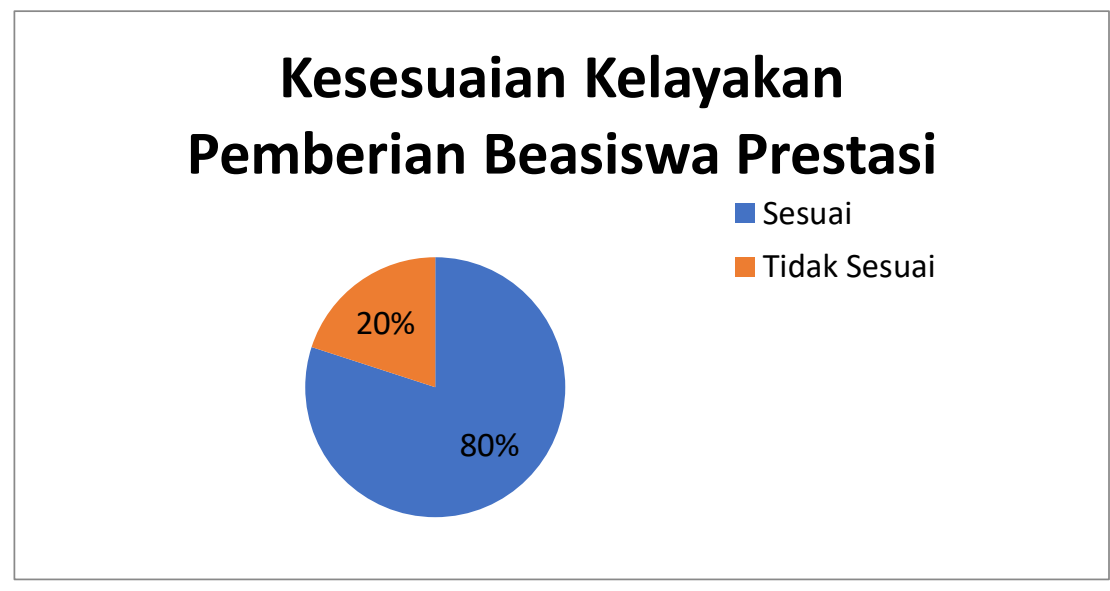

Gambar 10. Kesesuaian Kelayakan Pemberian Beasiswa Prestasi

\section{KESIMPULAN}

Dari hasil analisis yang telah dilakukan, maka dapat di tarik kesimpulan bahwa algoritma fuzzy tsukamoto dapat diterapkan dan digunakan dalam pembuatan sistem pendukung keputusan. Akurasi sistem yang diperoleh sebesar $80 \%$ yang berati bahwa sistem tersebut dapat digunakan dalam menentukan keputusan. Sistem pendukung keputusan yang dibuat dapat dijadikan sebagai pedoman petugas untuk mebantu menyeleksi calon penerima beasiswa prestasi Universitas Amikom.

Adapun saran untuk pengembangan ke penelitian selanjutnya yaitu aplikasi ini dapat dikembangkan lebih lanjut dengan menambah fitur tambah kriteria dan sistem dapat melakukan penambahan rulebase secara otomatis, dan juga melakukan olah data statistik terhadap data kriteria dan data uji sehingga akurasi menjadi lebih optimal.

\section{REFERENCES}

[1] R. McLeod dan G.P. Shell. (2008). Sistem Informasi Manajemen. Jakarta : Salemba Empat

[2] Nanda Novita. (2016) . "Metode Fuzzy Tsukamoto Untuk Menentukan Beasiswa." Jurnal \& Penelitian Teknik Informatika.

[3] Sri Kusumadewi dan Hari Purnomo.(2010). Aplikasi Logika Fuzzy untuk Pendukung Keputusan. Edisi 2. Yogyakarta : Graha Ilmu

[4] Turban E, Jay E.A Liang T.P. (2005). Decision Support System and Intelligent System. Edisi 7. Yogyakarta : Andi Offset

[5] Muhammad Arhami.(2005). Konsep Dasar Sistem Pakar. Yogyakarta : Andi Offset

[6] Sulaksana,U. (2004). Managemen Perubahan, Yogyakarta: Pustaka Pelajar Offset.

[7] Madya, S, (2006) Teori dan Praktik Penelitian Tindakan (Action Research), Bandung : Alfabeta.

[8] Kemmis, Stephen \& Mc Taggart, Robin (1988). The Action Research Planner. Geelong Victoria: Deakin University. 